\title{
Following the 52nd National Neurology Congress
}

\section{Ulusal Nöroloji Kongresi’nin Ardından}

The 52nd National Neurology Congress was held in Antalya between November 25th and December 1st, 2016. The main theme of the congress was "Vascular Neurology". After the opening speech by Professor Şerefnur Öztürk, Science and Service Awards were presented to Professor Aynur Baslo, and Associate Professor Arif Çelebi.

The first speaker of the first day of the main congress was Professor Turgay Dalkara. The title of his presentation was "Developments in the Pathogenesis of Ischemic Stroke". He stated that stressing upon time was partially true for thrombolytic treatments and he referred to the "Diffusion and Perfusion Imaging Evaluation for Understanding Stroke Evolution-2" trial, which provided evidence about beneficial effects of reperfusion even after the first 6 hours in patients with diffusion-perfusion mismatch. On the other hand, he stated that successful reperfusion could not always be achievable after recanalization, and at this point, he addressed the effects of microvascular damage due to ischemiareperfusion after recanalization in focal cerebral ischemia. Professor Dalkara concluded that effectively controlling oxidative stress due to ischemia-reperfusion, which occur during recanalization, is a required but ignored topic to increase the success of thrombolysis and neuroprotection. He invited young neurologists to study this subject.

On the second day of the congress, Professor Reha Tolun discussed the history of Vascular Neurology in Turkey and in the world, and he stated that Interventional Vascular Neurology has been established as a subspecialty of neurology and it has been developing. Two foreign guests of Vascular Neurology Session were Drs Tudor G. Jovin and Mayank Goyal who addressed current issues starting with the motto "time is brain". Jovin stressed that decreasing door-to- needle time below 30 minutes, which is important for increasing the success of endovascular thrombectomy, would be possible only if conventional imaging techniques were abandoned and patients were taken directly to the angiography. He called upon interventional neurologists to think about a novel strategy.

Stroke in Young Fabry Patients (SIFAP) was an interesting study presented in this congress. This prospective, observational, multicenter European trial, which was presented by Dr Arndt Rolfs from Rostock University, described a cohort of young patients with stroke. The primary aim of this study was to more precisely define the incidence of Fabry disease, and its secondary aim was to evaluate causes of stroke and risks associated with it in a young cohort of patients. This study involved 5023 patients aged between 18-55 years who were diagnosed with ischemic hemorrhagic stroke and transient ischemic attack between April 2007 and January 2010, in 47 centers. The results of the analyses supported the presence of Fabry disease in more than $1 \%$ of young patients with stroke. The disease was more prevalent in younger patients and the most common presentation was ischemic stroke, followed by transient ischemic attack. The results supported data that Fabry-related mutations S126G and A143T were associated with a phenotype that only has stroke in its course. This disease, which can involve multiple organs, may be mono-symptomatic and the presenting feature may be stroke. While summarizing his presentation, Rolfs gave the example of an iceberg model. He stressed that Fabry disease should be kept in mind in patients whose first presentation was ischemic stroke, in non-diabetic young women with thinfiber neuropathy, and in patients who have atypical demyelinating features in neuroimaging. Afterwards, Associate Professor Derya

Address for Correspondence/Yazışma Adresi: İpek Güngör Doğan MD, Darıca Farabi State Hospital, Clinic of Neurology, Kocaeli, Turkey

Phone: +905355106577 E-mail: dripekgngr@gmail.com

Received/Geliş Tarihi: 10.01.2017 Accepted/Kabul Tarihi: 10.01.2017

${ }^{\circ}$ Copyright 2017 by Turkish Neurological Society

Turkish Journal of Neurology published by Galenos Publishing House. 
Uludüz from İstanbul University Cerrahpaşa Faculty of Medicine and her colleagues presented the YOUNGFAR trial, in accordance with SIFAP, which involved patients aged $<55$ years with stroke in Turkey, and invited neurology clinics with stroke centers to participate in this trial.

Although the main theme of this congress was Vascular Neurology, exciting studies about many topics of neurology were presented.

An Oral Presentation Award was given to Associate Professor Hacer Durmuş and her colleagues who presented the largest cohort study in our country about congenital myasthenic syndromes (CMS), and described a desmin-related CMS and a new CMS phenotype secondary to GFTP1 mutation with a prominent distal involvement.

One of the promising studies was the biomarker study about HOXB3 protein, which strongly predicted conversion from clinically isolated syndrome (CIS) to multiple sclerosis (MS) in cerebrospinal fluid (CSF) evaluations. Comparing CSF evaluations of patients who presented to İstanbul University İstanbul Faculty of Medicine, Demyelinating Diseases Clinic with CIS and converted $(n=20)$ or not converted $(n=22)$ to MS in 5 years followup, HOXB3 level was strongly higher in the converted group and when combined with oligoclonal bands positivity; most patients with high HOXB3 levels developed MS within 5 years.

Another study was about video-oculography (VOG) in the diagnosis of Niemann-Pick type-C (NP-C), which is among the causes of treatable ataxias. The study screened 50 patients with degenerative ataxia without an identified etiology, because the clinical presentation of NP-C is common in cerebellar ataxia and vertical supranuclear gaze palsy (VSGP). Genetic evaluations were performed with a presumptive diagnosis of NP-C for three patients whose vertical saccades were impaired significantly more than horizontal, and the results were positive. Diagnosing VSGP, which is seen in NP-C with VOG at a stage when it cannot be detected by manual examination, was very exciting. 